\title{
Kamayas \\ Manipulation Of Expressive Symbol At Hindus Religious Practices In Mataram City
}

\author{
By: \\ I Wayan Ardhi Wirawan \\ Sekolah Tinggi Agama Hindu Negeri Gde Pudja Mataram \\ ardhiwirawan@stahn-gdepudja.ac.id
}

\begin{tabular}{l}
\hline \multicolumn{1}{c}{ Keywords: } \\
\hline Manipulation, \\
Expressive \\
Symbols, Religious \\
Practices, Hindu \\
Community \\
\hline
\end{tabular}

\begin{tabular}{l}
\hline Kata kunci: \\
\hline Manipulasi, \\
Simbol Ekspresif, \\
Praktek \\
Keagamaan, \\
Komunitas Hind
\end{tabular}

\begin{abstract}
This study aims to conduct a study of the manipulation of expressive symbol at Hindus religious practices in Mataram city, West Nusa Tenggara. The design of this research is interpretive descriptive by focusing on case studies the mechanism of manipulation expressive symbols at Hindu community. Based on the results of the study found that the mechanism of manipulation expressive symbol begins with cultural adaptation and reinterpretation of a number symbols used as a medium to realize the Vedic teachings. The mechanism of manipulation expressive symbol in this research systematic flow through at four domains, namely cultural adaptation of Hindus religious practices in the realm of expressive symbols, the synergization of expressive symbols in responding the development of science and technology, the representation of expressive symbol contestation in the dynamics of Hindu civilization, as well as the reproduction and reproduction of expressive symbols in Hindus religious practice.
\end{abstract}

\footnotetext{
Abstrak

Penelitian ini bertujuan untuk melakukan studi tentang manipulasi simbol ekspresif pada praktik keagamaan Hindu di kota Mataram, Nusa Tenggara Barat. Desain penelitian ini adalah deskriptif interpretatif dengan memfokuskan pada studi kasus mekanisme manipulasi simbol-simbol ekspresif pada komunitas Hindu. Berdasarkan hasil penelitian ditemukan bahwa mekanisme manipulasi simbol ekspresif dimulai dengan adaptasi budaya dan penafsiran kembali sejumlah simbol yang digunakan sebagai media untuk mewujudkan ajaran Veda. Mekanisme manipulasi simbol ekspresif dalam penelitian ini mengalir secara sistematis pada empat domain, yaitu adaptasi budaya atas praktik keagamaan Hindu dalam ranah simbol ekspresif, sinergisasi simbol ekspresif dalam merespons perkembangan ilmu pengetahuan dan teknologi, representasi kontestasi simbol ekspresif dalam dinamika peradaban Hindu, serta reproduksi dan reproduksi simbol-simbol ekspresif dalam praktik keagamaan Hindu.
} 


\section{Introduction}

The symbolic dimension in Hindu religious practice has a very important role related to efforts to realize of Vedic teachings. This phenomenon is indicated by the use of symbols as a medium to express belief in the presence of Supernatural power. The symbols used often experience dynamics in synergy with the development of human civilization. The dynamics do not only occur among Hindus who have a majority position, but also in a minority position that symbolic aspects in the practice of religion in the Hindu community in Mataram city, West Nusa Tenggara have been dynamics experiencing (Wirawan, 2006). One of these dynamics is based on cultural adaptation, namely the adjustment of religious practices to the influx of external cultural influences.

Cultural adaptations in realizing religious teachings occur, both at the physical and non-physical levels. Adaptation in the physical dimension is indicated by changes in symbolic forms, while in the non-physical dimension it deals with changes in behavior from Hindus that give meaning to the symbolic aspects that experience these dynamics.

The dynamics in the symbolic dimension as a reality in social-religious practice one of which is as an adaptation to the social environment. Environment adapted by humans continues to change, so in the adaptation effort humans continue to follow, observe, and interpret various symptoms and changes that occur in the environment dynamically (Triguna, 2001). Humans who assume how to adjust and give meaning that were previously less relevant, then there is a tendency that way will be replaced with a way that is assumed to be more appropriate after going through the mechanism of understanding and socialization.

Synergizing with the above phenomenon, Julian H. Steward argues that human evolution is not merely mere biology, instead it is an interaction between physical and cultural characteristics. Each characteristic influences each other (Garna, 1992). Although all elements of economic culture, technology, language, society and other elements can be seen from the interrelation of these elements and because they characterize a society at a certain stage, but the elements change according to the ways or directions that are certain, some are cumulative and some are adapted to sociopolitical and religious structures. 
With regard to efforts to synergize the symbolic dimension in the socio-cultural domain, Triguna suggests a terminology of symbolic manipulation (Triguna, 2001). The terminology is a way of promoting culture that is relevant and hiding that is less appropriate to the developing situation. In this way, at the same time showing tradition is not a continuum dealing with modernization, that one emphasizes localspecific way of thinking dealing with universalism-globalization.

Symbolic manipulation in the socio-cultural domain has a position to enter the realm of religious practice as it emerged in a number of Hindu religious groups with a minority position. This phenomenon occurs in the community in Mataram city, West Nusa Tenggara, which is indicated by efforts to prioritize Hindu practices that synergize with the development of human civilization. Symbolic manipulation is indicated by the process of production and reproduction of cultural symbols that resonate with Hindu religious practices. The process of production and reproduction of cultural symbols according to a number of people who want the dynamics in religious practices as an expression of the adaptation of religious practices with the development of the times, mainly synergizing between the implementation of religious teachings with socio-cultural changes. The main symbolic manipulation occurs in the expressive symbol dimension in Hindu practice. The expressive symbol dimension refers to Wallace and Alison Wolf, Parsudi Suparlan, Geertz is a symbol associated with the outpouring of feelings (Triguna, 2001). Expressive symbols in Hindu religious practice are articulated through the outpouring of feelings in realizing the teachings of the Vedic scriptures in the midst of religious activities such as expression of Vedic teachings in the form of rituality, construction of holy place, social organization systems, and the like.

Expressive symbols in Hindu religious practice as part of their close relation with the outpouring of feelings in realizing the Vedic teachings are contextually closely related to cultural adaptation. Regarding this phenomenon, Hindu practices which are full of symbolic nuances tend to experience adjustments to the development of human civilization. Cultural adaptation in expressive symbolic dimensions is indicated by the process of production and reproduction of religious symbols, especially those related to the expression of feelings. The process of producing and reproducing expressive religious symbols in the Hindu community in Mataram city synergizes with the development of the socio-cultural system in its environment. 
The manipulation of expressive symbols dimensions in the practice of Hinduism in Mataram city as a form of adaptation to the influence of dynamics in the socio-cultural system in its environment is passed through ways that prioritize relevant culture. Manipulation of expressive symbol dimensions in Hindu religious practices in Mataram City thus synergizes with the development of human civilization. Regarding this phenomenon, the process of producing and reproducing symbols in Hindu practice is a process of dynamic character. On another dimension, the process of producing and reproducing symbols in Hindu practice indicates that the sue generis process towards the symbolic aspects as expressed by Geertz does not always work.

Although symbolic manipulation is assumed as a form of adaptation of Hindu practices with the transformation of the socio-cultural system, it does not necessarily get a response from all groups. A number of groups, especially those who adhere to the status quo, resist resistance to socialreligious movements that seek to carry out manipulations at the level of religious symbols. The emergence of polarity towards symbolic manipulation at Hindus religious practice in Mataram city indicates that actual conflicts have emerged through verbal violence. The two groups with diametrically different views each build a discourse which in essence defends the truth of the ideational system adopted. Polarity between supporters of the process of symbolic manipulation and groups that carry out resistance if not managed properly has a proposition will lead to the occurrence of structural violence in realizing Hindu religious teachings.

Departing from the phenomenon above, in this study aims to conduct a study of mechanism of expressive symbols manipulation at Hindus religious practices in Mataram city. This study seeks to find answers to these problems as a vehicle for contributing to relevant parties in providing alternative solutions to the emergence of bipolarity between groups who want to reform Hinduism and the status quo group that seeks to conduct resilience. The results of this study are also expected to provide an understanding of the implementation dynamics religious practices as a form of response to the development of civilization entering modernization and globalization era. 


\section{Methods}

The study was designed in the type of interpretive qualitative research using a case study model. Regarding the implementation of the strategy, case studies provide opportunities for researchers to maintain the holistic and meaningful characteristics of real life events (Yin, 2004). Starting from this phenomenon the implementation of this study seeks to uncover contemporary events that emerge in the socio-religiosity domain, especially those related to the manipulation of expressive symbol dimensions in Hindu practice at the research location. The collected data is then grouped according to analysis needs. The grouping aims to systematize and simplify various data into units according to the level of analysis.

Regarding the implementation of research according to the place is a field research (Kartono, 1990). Based on this, the data collected was mostly derived from the phenomenon of social-religious life, especially related to the manipulation of expressive symbol dimensions in religious practices in the Hindu community in Mataram city. The qualitative data needed is related to symbolic phenomena in the middle of Hindu practice at the research location. The qualitative data obtained were then analyzed using established data analysis techniques in the presentation through narrative texts in the form of expressions, words, ideas or ideas, opinions, and notes relating to the problem under study. Qualitative data sources place the data source as a subject that has an important position (Tobroni, 2001). Consequently, the accuracy in choosing and determining the source of data as a determinant of the wealth of data obtained.

The data source of this study consisted of two sources, namely primary data and secondary sources. Primary data sources are informants and socio-religiosity activities related to the manipulation of expressive symbol dimensions which are actualized by the Hindu community in Mataram city, West Nusa Tenggara. The informant as the primary data source is positioned to provide information in accordance with the data needed in the research that was explored through interviews. Social-religious activities used as primary data sources are expected to provide accurate information that is extracted through observation in the field. Secondary data obtained indirectly from the main source, but obtained through the study of documents which include archives from various agencies, statistical data and monographs. 
Research data collection techniques are done through observation, interviews, and document studies. In observing the research object, the researcher previously involved himself in every important activity at the research location, first identifying the groups that influence the community's environment. This phenomenon is based on preliminary data that has been collected that among Hindus in Mataram city there are a number of groups that have a significant influence which has an influence on the administration of Hinduism. The aim is to facilitate controlling in observation, so that the diversity of objects that must be observed can be avoided.

The interview technique is done by determining the informants through a purposive technique, which is related to the objectives set. This study uses unstructured interview techniques unstructured interviews (unstructured interviews) provide more space than other types of interviews (Frey, 2009). Fontana and Frey cited Malinowski as saying that unstructured interviews were used to understand the complexity of the behavior of community members in the absence of a priori categories that could limit the wealth of data that could be obtained. In an effort to explore the data in this study unstructured interview techniques are very effective in digging indepth data because they are based on the reason the researcher's relationship with the informant can be maintained.

Document study techniques as a secondary data source. Sources of documents used in this study include documents in the form of archives from various agencies, literature, journals, statistics and other relevant references. Secondary data obtained from documentary sources are then analyzed according to the data analysis technique used. Document study is a way of collecting data through written relics in the form of archives, and also using library studies (Nawawi, 1983). The archives were obtained from a number of sources both institutional and non-institutional. Literature study in the form of books, opinions, theories, propositions/laws and others related to research problems.

This research uses interpretive descriptive analysis. The process of data analysis is done by organizing and sorting data into patterns, categories and units so that it is easy to draw conclusions. The process of data analysis in this study was carried out with three stages namely classification, reduction and interpretation of data. Data classification is the stage of grouping data obtained based on data collection techniques during data mining in the field. According to Bogdan and Biklen at the end of the 
analysis during data collection the objectives of data collection are determined (Tobroni, 2001). Data collected both from informants, situations, and documents were determined.

Data reduction in this study through the process of selecting, focusing and simplifying rough data taken from the author's notes during data collection in the field. Actually the reduction is not only carried out after all data is obtained, but continues throughout the study. Data reduction according to Miles and Huberman is a process of selecting, focusing on simplification, abstracting, transformation of rough data, which arises from field notes (Tobroni, 2001). Data reduction continues throughout the study. Before the data is actually collected, anticipation of a reduction is already apparent when the research decides the conceptual framework of the research area, the research problem and the data collection approach chosen.

Interpretation is carried out during the research process starting from data retrieval which aims to obtain meaning, specifically related to the object of research. Theory functions in an interpretive science suggests that the distinction, which is relative in any case, seen in experimental or observational sciences, between description and explanation here appears as distinction, which even more relative between writing and specification, that is, between writing the meaning of specific social actions for the actors whose actions are written, and stated, as explicitly as can be attempted, what is then shown about that knowledge about the community where it is found, and more than that about social life as it is (Geertz, 2001).

\section{Results and Discussion}

The mechanism of expressive symbols manipulation at Hindus religious practices in Mataram City is in accordance with the results of this study, indicated by the four domains of schematics, namely cultural adaptation of Hindus religious practices in the realm of expressive symbols, the synergization of expressive symbols in responding the development of science and technology, the representation of expressive symbol contestation in the dynamics of Hindu civilization, as well as the reproduction and reproduction of expressive symbols in Hindus religious practice.The four areas of schematics are analyzed in the following sections. 


\section{Cultural Adaptation of Hindu Religious Practices in the Field of Expressive Symbols}

Expressive symbols in Hindu religious practice are oriented towards symbols related to the expression of feelings which are ontologically related to the basic nature of the outpouring of feelings. Synergizing with this phenomenon the expressive symbol dimension is a symbol that involves aspects of bhava (emotion) and involves feeling as the climax attached to the values of Hindu beliefs in realizing the Vedic teaching, especially in the Hindu community, in Mataram city. The media used to express the dimensions of expressive symbols are more emperative so that in their manifestation it is more visible, which can be observed directly through the outpouring of feelings that realize Hindu religious doctrines in everyday life.

The dimension of expressive symbols in Hindu religious practice as a symbolic medium related to the expression of feelings. This study focuses on the dimensions of expressive symbols in three domains such as the symbol of the sanctuary, the symbol of rhythm, and the symbol relating to the system of social organization. Symbols of religious holy place in the middle of the Hindu community in Mataram city in general are divided into two, namely, a sacred place in the family environment and in a large scale community. Sacred places in the family environment are also divided into nuclear family and extended family. The nuclear family is a small family, while the extended family is a family that consists of a number of nuclear families.

The existence of holy place on a larger scale, namely in the form of pura (temples) can be divided into three categories. First, pura jagat (the general temple), pura fungsional (functional temple), and pura kawitan (ancestral temple). Pura jagat is also often referred to as a public temple, a temple that is used as a place for religious activities in all walks of life. With regard to this phenomenon, more specifically the general temple is used as a place of worship for Hindus who are not limited by the clan. Second, pura fungsional or the functional temple is a place for religious activities among people who have the same profession. Functional temples are used as places of worship for Hindus who have the same livelihood. Third, pura kawitan or kawitan temple is a place to do religious activities on Hindus who have genealogical similarities, which are in one clan or lineage.

The inclusion of spirituality ideology influence has significant implications for the color of Hindu religious practices, especially in urban areas as happened in 
Mataram city. The dimensions of expressive symbols are also impermeable to the influence spread by groups of spirituality followers. This phenomenon is indicated by a number of dimensions of expressive symbols in the practice of Hinduism experiencing dynamics. Religious holy place traditionally also experience dynamics. Hindus in Mataram city not only use a sacred place in the form of pura or sanggah as a place to carry out religious activities, but began to use the mandir, holy room, and other terms. The sacred places mentioned later are models for relatively new religious activities in Mataram city .

The dynamics in the domain of religious holy place by the existence of two groups with different views in addressing the existence of the place of worship. The first group is a group that assumes that the variants that emerge as expressions of feeling in realizing Hindu teachings in the form of holy place are freedoms that should be given space. In connection with this phenomenon, the existence of models of holy place as a form of appreciation of the divine aspect and at the same time as a vehicle to realize the teachings of Hinduism should be given freedom. The second group holds that religious practice in the Hindu community in Lombok is an ancestral heritage that must be preserved. Therefore the latter group is still not pleased with the existence of models of holy place that are incompatible with ancestral cultural traditions.

The emergence of polarity is part of the growth of critical attitudes among Hindus. This phenomenon also indicates that in the practice of Hindu religious life critical thinking is also very necessary so that the doctrines taught in the Vedic teching do not become standard entities. The critical attitude in responding to the implementation of Hindu teachings has indeed grown since the sutreraa and scholastic periods. The sutra era is the time of the writing of philosophical thoughts in the form of sutra, namely short, solid, and subtle expressions in Sanskrit. While the scholastic period is the birth of scholars who provide interpretations to existing systems. In fact it is very difficult to separate between the sutra era and the scholastic period. At this time the birth of dialectics of thought through philosophical debate and the science of logic.

The seeds of philosophical thought in the sutra and scholastic times in civilization in India which provided space for critical thoughts on aspects of Vedic teachings were a progress. This critical aspect opened space for changes in the administration of Vedic teachings in the life of the Hindu community in India at that 
time. Associated with the existence of critical thoughts among Hindus in Lombok in responding to changes in the implementation of Hinduism, especially concerning expressive symbolic dimensions is a progress in the context of adapting religious practices in the midst of accelerating sociocultural change. This phenomenon is in line with the phrase conveyed by I Gusti Lanang Media (an informant) which basically states that the implementation of religion in the midst of Hindu life in the future should be returned to the nature of religion itself. Religious life should be able to keep up with the times. But the implementation of religion should be forced upon the times. The fact shows that to make changes is very difficult. In addition, the changes also cause problems because most Hindus.

Changes in the implementation of Hinduism in the view of the reformer group are assumed to be a sacrifice that has a reference to the religious scriptures. This phenomenon is revealed in the interview excerpt with I Gusti Ngurah Sunarta (an informant) who revealed that those who want change must respect the gods of change, that is Dewa Wishnu or Dewa Hari. Every initiation of the puja says Hari Om. The concept of aja wera (Hindus teaching about don't look down on) is indeed good, especially in terms of its positive aspects. In this context do not actualize the concept of aja wera too hard. Whereas the concept of ayua wera in this matter let us not preach this knowledge to those who do not perform asceticism or sacrifice. In the final section of the Bhagavad Gita it is mentioned that those who teach this knowledge "to My people or My worshipers will come to Me". Therefore I am very passionate about this because I am sure it will provide benefits, I return to the subtle body to see the benefits.

The important entity that is implied behind the narrative emphasized by the informant above is the changes made in the implementation of Hinduism should have a positive direction in improving the quality of diversity. The teachings of Hinduism open up opportunities for change that is indicated by the appeal which is stated that making changes should always ask for guidance and direction in a spiritual direction to the gods of change. The analogy above which identifies change has similarities with the development of living things can build the conclusion that change is a necessity but its nature is still gradative. There are changes that are fast and some are slow. Associated with changes in the procedure for implementing Hinduism, sooner or later a change depends on the environmental conditions in which Hinduism grows and develops. With regard to the periodization of change, Koentjaraningrat argues that the 
changes that occur within a period of several generations of generations are not the same in one human collective and another human collective (Koentjaraningrat, 2003). Some people need a century or two to experience a change, but some experience it only in two or three generations. The process of change that is different in various places on earth causes that the unions of human life throughout the world vary greatly.

\section{Synergization of expressive symbols in responding the development of science and technology}

Manipulation of symbolic dimensions assumed to be less relevant to the situation and conditions that are developing (Triguna, 2001). Synergizing with this phenomenon, the traditions that have existed and are hereditary for generations within the Hindu community in Mataram city are faced with modernization/globalization. These preserved traditions show a more local character, whereas modernization/globalization is the opposite, which shows a universalist character. The character of traditionality thinking has a more specific tendency, while modernization tends to be more global. The binary opposing character between traditionality and modernity becomes the background of cultural adaptation in order to build synergy between the two. The comparison between traditionality and modernity does not always lead to differences in direction, but can be synergized so that the two are able to complement each other. Regarding this phenomenon, modernization and traditionalism are complementary. This reality reinforces the opinion of Apter who argues that modernity and traditionalism are linked together in a fundamental way, even in the context of modernization. The synthesis is the main moral focus.

The symbols used as a medium to realize religious teachings in the midst of Hindu religious practices in Mataram city are the product of traditional production by the people. The production of these symbols is adjusted to the circumstances when the teachings of Hinduism are realized in social-religious life. The use of symbols in the administration of Hinduism in Lombok, especially in Mataram city is almost similar to the symbols used by ethnic Balinese Hindus. The condition is based on historical factors, namely the existence of Hindus in Lombok brought by ethnic Balinese people who came and settled in Lombok since hundreds of years ago. Likewise, the existence of expressive symbol dimensions used in Hindu practices also has similarities to those used in Bali. Only a number of aspects of expressive symbols that have differences 
caused by power factors, namely the power of Karangasem King when expanding power to Lombok to build an expressive symbol system in order to organize social, cultural, and religious life in new settlements in Lombok.

Differences in expressive symbol dimensions between Hindus in Bali and Hindus in Lombok in the course of history are only in the limits that are not too substantial. This phenomenon is like in the kinship system of sidhikara which is used as a vehicle to help resolve the order of religious rhythm which involves communal community participation. Sidhikara in the social-religious life of the Hindu community in Lombok is generally used as a medium to build mutual cooperation in completing the implementation of religious rituals such as manusa yajna (one of which is a marriage ceremony), pitra yajna (burial or carrying out a cremation ceremony). The use of sidhikara is more expressive in a number of Hindu religious rites in Lombok as well because the social system prevailing in Lombok with Bali has differences. The Hindu community in Bali has a banjar system and desa pakraman (Balinese traditional organization in village) that assist in the process of implementing religious rhythm, while the system is not found in the Hindu community in Lombok.

The arrangement of social-religious life in the Hindu community in Lombok in the historical perspective of its authority rests with the king's authority. King of Karangasem Kingdom as the top leader of the Balinese people who came to Lombok around the sixteenth century had a very central role in building social, cultural, and religious order. Regarding this phenomenon, the religious symbols in the middle of the Hindu community in Lombok are not entirely the same as the religious symbols used by the Hindu community in Bali. This phenomenon synergizes with the concept put forward by Abdullah by basing on Thrift and Miller reaffirming that the meaning of a symbol due to melting cultural boundaries is largely determined by the changing structure of power relations (Abdullah, 2006). A culture cannot be separated from the space where it was built, maintained, preserved, and even changed. The problem is that the space that becomes the place where the culture is located has experienced redefinition in line with the growth of the city and modern lifestyles which are directly preceded by changes in spatial design. 


\section{Representation of Hindu contestation in the dimension of expressive symbols}

The representation of Hindu contestation based on the results of field observations in this study is a polarization event that took place between the support groups and on the other hand there are groups opposing the manipulation of the expressive symbol dimension. Both groups are contesting through verbal expressions. Those who support assume that the implementation of Hinduism should be adapted to the development of civilization, in this context in the form of cultural adaptation. Cultural adaptation promotes religious practices adapted to the development of human civilization. The practice of religion as a realization of religious teachings is the realm of cultural practice. Manipulation of religious symbols in a constructive socialy by referring to ideas of Pierre Bourdieu and Bactiar Alam (Kumbara, 2004). Following the aforementioned thinking, culture is seen as not at all outlined by its nature (sui generis), but rather created and constructed by its own participants so that it depends on the actors. This cultural theory emphasizes the involvement of the "subject" in the process of cultural construction. Culture is never given, but social constructive. The manipulation of religious symbols by referring to Bourdieu is a social reality that indicates the construction of cultural symbols (Bourdieu, 1991). Cultural practices are not just accepted and continued, but through a process of selection, adaptation, and restructuring.

In paying close attention to the contestation between the cloudy and those who reject the manipulation of the expressive symbol dimension in the practice of Hinduism in Mataram city are closely related to the aspect of power. That power can be in the form of visible power and can also be invisible power. Visible power is power that tends to appear in the form of domination. Power as a tool to maintain state domination (Fashri, 2007). Machiavelli's view emphasizes that power is not a tool that serves the good, welfare, welfare of even God. Power reflects itself as a tool that only serves the interests of the state alone.

Based on the definition of power as summarized above, power is synonymous with efforts to establish dominance. Power in this context power is implemented in actions that are used as instruments to serve the interests of the state. Power in relation to this matter has the opportunity to become a superordinate which can be manifested by force. Representation of truth through a symbolic universe was able to create a social mechanism in which there was a link between power and violence (Fashri, 2007). 
Representations that should contain harmony between the signs produced and what they represent often obscure the actual reality.

Regarding the presence of symbolic power, power can not always be presented in the form of violence, but it can also be manifested in a very subtle form so that its existence seems difficult to recognize. Such power was identified by Pierre Bourdieu as symbolic power. Symbolic power is produced by symbolic power. Referring to Pierre Bourdieu symbolic power is an invisible force --- and is distorted - but it is recognized as legitimated. As Bourdieu said, "what creates the power of words and slogans, a force capable of defending or subverting social order, is the belief in the legitimacy of the words and the person who utters them (Piliang, 2005). A language or symbol is considered legitimate or illegitimate depending on who says it. In a political context, if the person who says a word is someone who is given authority and gets legitimacy, then his words are considered as truth.

Symbolic power is related to the process of production and reproduction of religious symbols, especially in the midst of Hindu religious practices whose position is to construct symbolic manipulation. The power that becomes the driving force in the process of manipulation of symbolic dimensions, especially expressive religious symbol dimensions in the Hindu community in Mataram city is more likely to be driven by symbolic power. The discourse delivered by groups of people who want a change in symbolic forms of Hindu religious practice is packaged in a media that is able to convince people of the ideas put forward. These ideas are often legitimized by the texts contained in the Vedic scriptures and their texts so that the interests that sneak behind symbolic manipulation are invisible. Hindus will more easily accept the ideas put forward because they assume the truth contained in the discourse does have valid references in the scriptures. The mechanism of manipulation of the religious symbol dimension in such ways will be easier to realize so that there is not much resistance from the people.

The power that sneaks behind the manipulation of the expressive symbol dimension in the middle of the eragama practice of the Hindu community in Mataram city is so subtle that it seems as if it cannot be identified. The discourse delivered through language media has the tendency to build ideology in individuals so that it is indirectly able to influence the mindset and patterns of individual action. Such phenomena as happened in building discourse simplify aspects of the upakara 
(ceremonial means) used in rituals practiced by the Hindu community in Lombok, especially in Mataram city. Religious rituals practiced by the Hindu community in Lombok in the historical range are assumed to be very complex, so simplification is needed. Simplification in terms of rituality on the other hand is recommended to improve aspects of spirituality. The discourse as expressed by I Made Metu Dahana (an informant) revealed that the religious community today is most appropriate to change the orientation of religious understanding. Simplifying rituals in the implementation of religion is very necessary. But on the other hand it should be enhanced by carrying out spiritual activities. Decreasing the level of rituals and increasing spiritual levels are the most suitable religious patterns practiced today.

Synergizing with the ideas expressed by the informants above, there is an effort to reduce the level of religious rhythm by deepening the aspects of religious philosophy. The idea was conveyed by I Gusti Lanang Ngurah Weda (an informant) revealed that the practice of religion that is too full of ritual weights sometimes lacks an understanding of religion in the form of religious philosophy. The practice of religion that is not accompanied by an understanding of aspects of religious philosophy is also inappropriate. Thus religious knowledge in the form of religious philosophy should be deepened. Many things can be done to support this. One of them is by reducing the weight of the ritual and more oriented to service and an increase in knowledge about the Godhead.

The two informants above have similarities in ideas, namely they both want a change in Hindu practice. The two informants above wanted a reduction in the aspects of rituality and on the other hand they wanted to increase the understanding of Hindus in the aspect of religious philosophy. The ideas expressed by the informants above related to the teachings of Hinduism have references. The teachings of catue marga describe the way for Hindus in realizing religious teachings. Catur marga are the four main spiritual paths to realize God. According to Sivananda namely karma marga/yoga, bhakti marga/yoga, raja marga/yoga and jnana marga/yoga. In realizing the four roads is largely determined by the individual temperament. This is as a consequence of the adaptive ways offered by the character of the people in realizing the condition of their spirituality as an implementation of the appreciation and practice of religious teachings. As is well known, in realizing the spiritual aspect in the form of actions the mood aspect is very significant. 
The emergence of a discourse that wants changes in the implementation of religious procedures involving expressive symbol dimensions at Hidus religious practice in Mataram city as in the realm of religious rituals as narrated by the informant above indicates the manipulation of religious expressive symbol dimensions which are based on aspects of interests and power. Interests in this context are the interests of cultural adaptation of Hindu practices to the development of civilization. The entry of the influence of modernization has a significant influence on the order of sociocultural life. Modernism tends to replace tradition with a new one the image of modernism is one of the attractions, the promise of technological progress, and to which tradition is replaced with a new one (Barker, 2004). This is a world of social progress, urban development and self-disclosure.

The link between modernism and social-religious life among Hindus is the opportunity for products produced by technological advances to be used as substituents in Hindu religious symbols. The use of modernization products in the domain of religious expressive symbols in the midst of religious practices in the Hindu community in Mataram city is more dominant in the aspect of religious rhythm. A number of elements of upakara (ceremonial means) use the tools produced by technological developments as a substitute for upakara materials for some reason. First, the means used as materials for the existence of increasingly scarce means the results of technological developments are used as a substitute. Second, in terms of practicality, a number of elements of ceremonial means are substituted with products resulting from technological development. This phenomenon is indicated by the use of items made of metal and plastic used as a substituent of ceremonial tools based on soil or plants. Simple substitution facilities such as kolak (place of tirta or holy water), which used banana leaves, were recently substituted using plastic or metal-based containers. The place of banten (offerings) that used to dulang use a wooden-based dish was substituted with metal-based material. The use of ritual means that use the results of modern technology is very practical to be used as a substituent for ceremonial facilities based on soil or plants. 


\section{Production and Reproduction of Expressive Symbols in Hindu Religious Practices}

The use of the results of the production of modern technology that is used as a vehicle helps the implementation of religious rituals in the middle of the Hindu practice of relatively many models. Based on the results of field observations it was found that the results of the production of modern technology greatly helped facilitate the implementation of religious rituals. This can be seen in the use of transportation as a tool in accelerating the process of carrying out ceremonies such as nunas tirta (requesting holy water) in several holy places which are relatively far away. Traditions that apply since the historical period, for Hindus in Lombok who carry out large-scale ceremonies such as rsi gana ritual in a sacred place, both in the family and in the temple perform activities nunas tirta to a number of holy sites as a complement to the implementation of the ceremony. In the past they carried out these activities by walking or using simple means of transportation. The development of modern technology such as cars has helped the people in accelerating the process of carrying out the nunas tirta activity in a number of designated holy sites.

The existence of modern transportation in the implementation of religion which tends to give a positive sentiment was also stated by I Wayan Budiartha (an informant) argues that the existence of modern transportation in Hindu life is very helpful especially related to ritual activities, such as in nuur tirta activities (asking holy water in a relatively far-away place, taking banten (a means of ritual) in a faraway place, pushing the pedanda (fetching a priest) will be faster in the process. With the existence of modern transportation, it will greatly help the smooth process of carrying out religious ritual activities

The inclusion of transportation technology in the midst of Hindu practices also has significant implications for the process of cultural adaptation, especially with the inclusion of means of transportation as part of expressive symbols. This phenomenon is indicated by the growing belief among Hindus that the results of modern technology such as means of transportation have an invisible force that controls the course of the vehicle. This belief is proposing to build a new symbol system, namely the means of transportation attached to the value of religiousness. Regarding this phenomenon, modern transportation is treated as an entity that has a spirit, so that it is often found that the means of transportation are given a ritual and a ceremony. The belief system is 
further strengthened by determining the right momentum to pay homage to the spirit that controls these tools, namely the calculation of the traditional calendar saniscara kliwon wuku landep. On that day Hindus refer to as the holy day of Tumpek Landep, which is a holy day as worship of the gods the master of sarwa landep (objects / sharp weapons) in Hindu teachings is worshiped as the God of Pasupati.

Based on the above phenomenon, expressive symbols in Hindu practice experience production and reproduction along with the development of civilization. Modern technology has created instruments that can facilitate the implementation of religion so that it gives meaning to the lives of Hindus tend to be symbolically respected. The symbolic respect involves a belief system so that the practice of Hinduism also links aspects of belief with technology as part of modernization. The production of expressive symbols in Hindu religious practices related to the cultural dimension is a process of cultural construction. In connection with this phenomenon Bactiar Alam asserted that culture is seen as not at all outlined by nature (sui generis), but rather created and constructed by its own participants so that it depends on the actors (Kumbara, 2004).

Based on the above phenomenon it is revealed that the results of the production of modern technology are used as a means to assist the process of carrying out religious activities, especially those concerning the implementation of religious ceremonies as part of the expressive symbol dimension. The use of the results of the production of modern technology, both used directly in religious ceremonies such as used as a substituent for a number of ceremonial facilities whose existence is difficult to find / in terms of their practicality or used as a vehicle to support the implementation of religious ceremonies such as means of transportation, including supporting the implementation of other ceremonies. The use of the results of advances in modern technology in ritual activities is also part of the process of manipulation of expressive symbol dimensions in the midst of religious practices in the Hindu community in Mataram city. This phenomenon indicates that the manipulation of the religious expressive symbol dimension is one of which is determined by the results of the development of modern technology.

The use of facilities resulting from the production of modern technological advances in Hindu religious practices such as described in the previous section should not reduce the implicit meaning behind the practice of the religion. The tendency that 
occurs as an implication of the development of modern technology is the occurrence of secularization in religious life that in the last century the increase in economic rationalization, indutrialization, urbanization, and advancement of science has led to the widespread secularisation of modern industrial society (Sanderson, 2003). Sanderson's expression is associated with the practice of Hindu religious life as an opportunity to give rise to rationality in the dimension of religious symbols. Rationalization that leads to secularisation opens up opportunities for the void of meaning implied in religious activities.

The manipulation of the expressive symbol's dimension in the Hindu community in Mataram city as in the candra at the top is related to the terminology put forward by Al Andang as an orthopraxic process in Hindu practice. Al Andang formulates that orthopraxis of religious teachings according to Andang is an effort to ground religion into an emancipative effort, an effort that respects all forms of life with its complexity (Andang, 1998). Religion needs to continue to maintain the ethos of searching for human transcendental meaning but without forgetting its praxis estuary. In relation to the dynamics in the system of religious symbols as a consequence of the influence of the production of science and technology triggers rationality in the implementation of religious teachings. The rationality of religious aspects involves the simplification and substitution of aspects of the religious symbolic system, especially in the dimensions of religious rituals. The dynamics in the symbol system that follows the development of society is also corroborated by Bourdieu who reveal that symbols can be changed by their supporting societies along with the development and demands of the times (Harker, Richad, 1990).

\section{Conclusion}

The manipulation of expressive symbol dimensions at Hindus religious practice in the in Mataram city begins with the process of cultural adaptation. The acceleration of socio-cultural change as an implication of science and technology development opens opportunities for the redefinition and reinterpretation of the symbolic dimension, especially the dimensions of the expressive symbols used in Hindu practice. The process of cultural adaptation is done by observing, following, and interpreting various phenomena that occur in their environment dynamically. Regarding this phenomenon the symbols used as media in realizing Hindu religious 
teachings which are assumed to be less relevant to the development of civilization are replaced with symbols that are assumed to be more relevant after passing through the mechanism of understanding and socialization. Manipulation of expressive symbols is actualized according to the results of this study through four domains, namely cultural adaptation of Hindus religious practices in the realm of expressive symbols, the synergization of expressive symbols in responding the development of science and technology, the representation of expressive symbol contestation in the dynamics of Hindu civilization, as well as the reproduction and reproduction of expressive symbols in Hindus religious practice.

Manipulation in expressive symbolic dimensions in the middle of Hindu practices in Mataram city is a form of cultural adaptation to the pace of sociocultural change in the environment should be given space in order to maintain the existence of the essence of the teachings of the Vedic scriptures contextually. The emergence of polarity which is implemented in a number of discourses, both accepting and refusing to deal with the manipulation of expressive symbol dimensions in Hindu religious practice is a necessity in order to realize the dynamics in social-religious life.

\section{References}

Andang, A. (1998). Agama Yang Berpijak Dan Berfihak. Yogyakarta: Kanisius.

Barker, C. (2004). Cultural studies, Teori Dan Praktek. Yogyakarta: Kreasi Kencana. Bourdieu, P. (1991). Language and Symbolic Power. Great Britain.

Fashri, F. (2007). Penyingkapan Kuasa Simbol; Apropriasi Reflektif Pemikiran Pierre Bourdieu. Yogyakarta: Juxtapose.

Frey, A. F. dan J. . (2009). Wawancara Seni Ilmu Pengetahuan" dalam buku Handbook of Qualitative Research (N. . D. dan Y. . Lincoln, Ed.). Yogyakarta: Pustaka Pelajar.

Garna, J. K. (1992). Teori-Teori Perubahan Sosial. Bandung: PPs-Universitas Padjadjaran.

Geertz, C. (2001). Agama Sebagai Sistem Kebudayaan" dalam buku Dekontruksi Kebenaran Kritik Tujuh Teori Agama. Yogyakarta: IRCiSoD.

Harker, Richad, C. M. dan C. W. (1990). Posisi Teoritis Dasar" dalam buku (habitus Modal) + Ranah = Praktik. Pengantar Paling Komprehensif Kepada Pemikiran Pierre Bourdieu. Yogyakarta: Jala Sutra.

Irwan Abdullah. (2006). Konstruksi dan Reproduksi Kebudayaan. Yogyakarta: Pustaka Pelajar.

Kartono. (1990). Pengantar Metodologi Riset Sosial. Bandung: Mandar Maju.

Koentjaraningrat. (2003). Pengantar Antropologi I. Jakarta: Rineka Cipta.

Kumbara, A. A. N. A. (2004). Etnisitas dan Kebangkitan Kembali Politik Aliran pada Era Reformasi: Perspektif Teoritis". dalam Buku Politik Kebudayaan dan Identitas Etnik. Denpasar: Fakultas Sastra Unud dan Balimangsi.

Nawawi, H. (1983). Metode Penelitian Bidang Sosial. Yogyakarta: Gajah Mada University Press. 
Piliang, Y. A. (2005). Transpolitika. Bandung: Jalasura.

Sanderson, S. . (2003). Makro Sosiologi. Jakarta: PT Raja Grafindo Persada.

Tobroni, S. I. dan. (2001). Metodologi Penelitian Sosial-Agama. Bandung: Remaja Rosdakarya.

Triguna, I. B. . (2001). Redifinisi Simbolisme Masyarakat Hindu Di Bali (Laporan Penelitian). Denpasar.

Wirawan, I. W. (2006). Dinamika dalam Sistem Simbol Kegamaan pada Komunitas Hindu di Kota Mataram, Provinsi Nusa Tenggara Barat. Universitas Udayana.

Yin, R. K. (2004). Studi Kasus, Desain \& Metode. Jakarta: Jakarta. 